
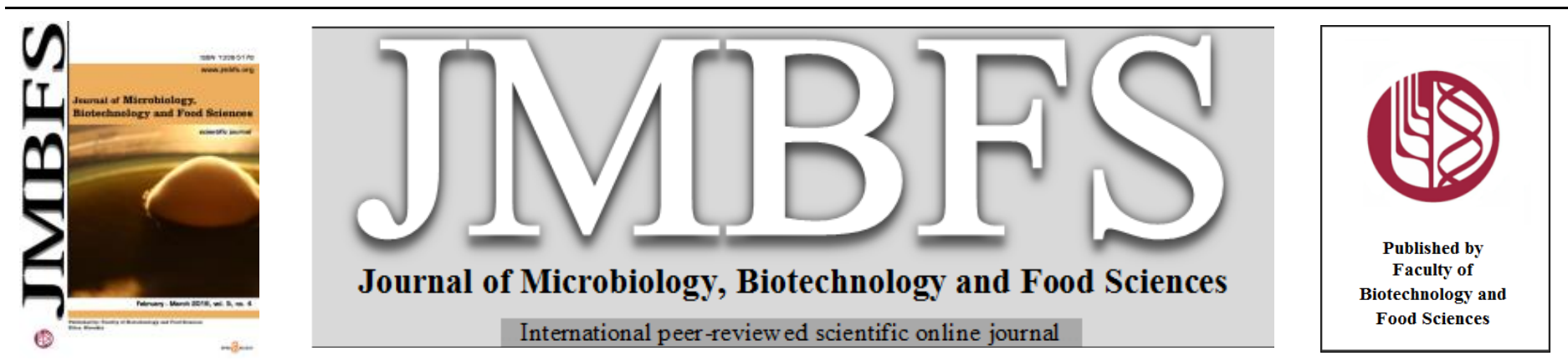

\title{
METABOLITE PROFILES AND ACCEPTABILITY BY CLUSTERS OF DIFFERENT KEFIR TYPES FOR SOUTH AFRICAN CONSUMERS
}

\author{
Armelle Lyvane Ntsame Affane ${ }^{* 1}$, Nina Muller ${ }^{2}$, Marieta Van der Wijst ${ }^{3}$, Gunnar Sigge ${ }^{2}$, Trevor J Britz ${ }^{2}$ \\ Address(es): Dr Armelle Lyvane Ntsame Affane \\ ${ }^{1}$ Ecole Normale Supérieure, Laboratoire des Sciences de la Vie et de la Terre, Rue des Ecoles, BP 17009 Libreville Gabon, 0024106364526. \\ ${ }^{2}$ Stellenbosch University, Faculty of AgriSciences, Food Science Department, Hammanshand road, Private Bag X1 Matieland 7602, South Africa. \\ ${ }^{3}$ Agricultural Research Council, Biometry Unit, Hammanshand road, Private Bag X1 Matieland 7602, South Africa.
}

*Corresponding author: anamie77@gmail.com

doi: $10.15414 / j m b f s .2016 .5 .4 .364-368$

\section{ARTICLE INFO}

Received 26. 8. 2014

Revised 31. 8. 2015

Accepted 25. 11. 2015

Published 1. 2. 2016

Regular article OPEN $\partial_{\text {ACCESS }}$

\section{ABSTRACT}

Kefir is an alternative fermented dairy product for low income South African consumers. However, it was shown that mass culturing of kefir grains leads to a loss of positive sensory attributes. Thus, this paper evaluates the chemical composition and the sensory acceptability for South African consumers of four variants of kefir (traditional kefir, mass-cultured kefir, Candi-kefir and Lacto-kefir). Results showed that all variants of kefir contained key flavour compounds: acetaldehyde $\left(7-45\right.$ mg.L $\left.\mathrm{L}^{-1}\right)$, ethanol $\left(186-1774 \mathrm{mg} . \mathrm{L}^{-1}\right)$, diacetyl (5 - $\left.12 \mathrm{mg} . \mathrm{L}^{-1}\right)$, ethyl acetate $\left(1,2-30 \mathrm{mg} \cdot \mathrm{L}^{-1}\right)$ and acetic acid $\left(892-4490 \mathrm{mg} \cdot \mathrm{L}^{-1}\right)$; with acidity (TA: 0,85 - 0,96\%; pH: 4,13$4,25)$ comparable with ranges reported in literature.

Based on the liking of flavour of the variants of kefir, three clusters of consumers $(\mathrm{N}=85)$ were identified using Ward's clustering. Cluster I was negatively sensitive to acidic products as indicated by the low scores $(<5,30)$ given for liking of flavour. For Cluster II consumers, the main driver of liking of flavour was ethanol $(r=0,963 ; p<0.05)$, therefore giving the best score $(7,5)$ to traditional kefir the most 'yeasty' variant. For cluster III, acidity was a significant driver of liking $(r=0,999 ; \mathrm{p}<0.05)$. Thus, less acidic kefir products obtained better consumer liking scores ranging between 7,09 and 7,63.

The results of this study add to the understanding of sensory attributes which drive consumer preference for kefir. This important information can be used by the South African dairy industry to strengthen the current market through the appropriate production of kefir.

Keywords: Kefir, consumer preference, acidity, flavour compounds, diacetyl to acetaldehyde ratio

\section{INTRODUCTION}

Milk and fermented dairy products are widely consumed in South Africa not only because they form a part of the traditional diet of South Africans (Van Wyk $\boldsymbol{e t}$ al., 2002), but also because of the health benefits associated with their regular consumption. Furthermore, these products have versatile uses and are available in a wide variety of flavours, making them enjoyable and interesting foodstuffs to consume (Shiratsuchi et al., 1994).

In recent years, even though new and/or improved fermented dairy products have appeared on the South African market, affordability still remains a problem for the vast majority of the population (Schönfeldt $\boldsymbol{e t}$ al., 2010). The fact that there has been an increase in the demand for yoghurt and maas (Coetzee, 2011) clearly demonstrates that there is a need for affordable good quality fermented dairy products similar to yogurt and maas in the South African dairy market. Maas is a traditional fermented milk made by fermenting raw milk in clays pots or calabashes. It is consumed by the rural inhabitants of South African villages (Kebede et al., 2007). The industrially made version of maas is also produced and available for people living in urban areas (Van Wyk et al., 2002).

Kefir, a fermented dairy product originating from the Caucasus Mountains (Doğan, 2011), has the potential to fill that market niche because it has several attributes, such as being home-made, having probiotic properties and having a well-balanced nutritional composition, that would make it an affordable and healthful fermented dairy product for South African consumers. Furthermore, kefir is similar to maas in many aspects and according to Burger (2010), "Kefir would taste similar to the maas connoisseur". Finally, the biggest advantage of this product is that kefir grains, the starter culture from which kefir is made, are endlessly reusable.

Mass production of kefir grains for distribution or selling is possible by using the mass cultivation procedure (Schoevers and Britz, 2003), which yields 'mass cultured kefir grains' (MG). These grains will be a more commercially viable option for kefir production as their culturing will be considerably more costeffective when compared to traditional grains. The drawback of these grains is that the resultant kefir beverage has an unpleasant flavour when compared the flavour of traditional kefir. The latter has a pronounced buttery flavour and slight to strong yeasty flavour, combined with a distinctive acidity essentially originating from lactic acid (Bakhshandeh et al., 2011). Since metabolites are synthesised by the symbiotic activity of the microbial consortium in the kefir grain, it is proposed that the lack of flavour in MG-kefir can be ascribed to an intrinsic microbial imbalance within the $\mathrm{MG}$ or the absence of a significant number of flavour forming microbes (Witthuhn et al., 2005). Thus enriching mass cultured kefir grains with flavour forming microorganism may improve the sensory character of MG kefir. In that regard, the objective of this study is to evaluate the metabolic profiles and establish the consumer preference of MG kefir, Traditional kefir and variants of MG kefir made from enriched mass cultured kefir grains.

\section{MATERIAL AND METHODS}

\section{Preparation of kefir}

Two batches of MG were separately enriched by adding Candida kefyr 1283 and Lactococcus lactis spp. lactis biovar. diacetylactis 318 to produce two new variants of mass cultured kefir grains, namely MGC (mass cultured grains with C. kefyr) and MGL (mass cultured grains with L. lactis spp. lactis biovar. diacetylactis). Kefir was produced from these grains as well as from mass cultured grains (MG), while kefir from traditional grains (TG) served as a control. Thus, it is obtained four variants of kefir.

For the preparation of the kefir variants, $20 \mathrm{~g}$ of kefir grains (MG, MGC, MGL and TG) were inoculated into $300 \mathrm{~mL}$ pasteurised milk. Milk inoculated with MG, MGC and MGL were incubated at $22^{\circ} \mathrm{C}$, whereas the traditional kefir was prepared under uncontrolled home-style conditions. After an incubation period of $24 \mathrm{~h}$, the grains were removed to obtain the final kefir beverages.

The kefir beverages were labelled as follows: Trad-kefir (kefir produced from TG), MG-kefir (kefir produced from MG), Lacto-kefir (kefir made from MGL) and Candi-kefir (kefir made from MGC). 
Metabolite profiles and acidity

The measurements of acidity as well as the quantification of short chain fatty acids and volatile organic compounds were done on the four variants of kefir.

\section{Volatile organic compounds determination}

Samples were prepared by placing $9.75 \mathrm{~mL}$ of kefir in a $20 \mathrm{~mL}$ glass via containing $2.5 \mathrm{~g} \mathrm{NaCl}$ and $0.25 \mathrm{~mL}$ tetrahydrofuran. The vial was crimp-sealed with a silicone-PTFE seal and aluminum cap and incubated in a waterbath for 50 $\min$ at $95^{\circ} \mathrm{C}$.

Separation and identification of volatile organic compounds (VOCs = acetaldehyde, ethanol, acetone, diacetyl, 2-butanone and ethyl acetate) present in kefir were determined using a Fisons 8000 Series gas chromatograph (FISONS INSTRUMENTS S.P.A., MILAN, ITALY). Details of the GC settings are fully described in previous works (Human, 1998; Ntsame Affane, 2012).

Quantitative determination of the metabolite compounds was done by integration of the peak areas using an external standard calibration and Borwin Version 1.2 integration software (JMBS DEVELOPMENTS, LE FONTANIL, FRANCE).

\section{Volatile short chain volatile fatty acids determination}

Samples were prepared by centrifuging $10 \mathrm{~mL}$ of Kefir for $10 \mathrm{~min}$ at $10000 \mathrm{~g}$. The resulting supernatant was filtered through Whatman paper No. 1 filter to remove solid particles and obtain a clear supernatant. One $\mathrm{mL}$ of formic acid (35\% v. $\mathrm{v}^{-1}$ ) and $2 \mu \mathrm{L}$ of $\mathrm{n}$-hexanol (as internal standard) were added to $3 \mathrm{~mL}$ of the filtered supernatant.

The short chain volatile fatty acids (VFAs) were determined using a Varian 3700 gas chromatograph (Palo Alto, California, USA) equipped with a flame ionisation detector and a $30 \mathrm{~m}$ bonded phase Nukol (Supelco, Inc., Belafonte, PA, USA) fused silica capillary column $(0.53 \mathrm{~mm}$ diameter and $0.5 \mu \mathrm{m}$ film thickness $)$. The details of the method can be found in previous works (Sigge et al., 2005; Ntsame Affane, 2012). VFAs were quantified using the Borwin Version 1.2 integration software (JMBS DEVELOPMENTS, LE FONTANIL, FRANCE).

\section{Titratable acidity and $\mathrm{pH}$ measurements}

The $\mathrm{pH}$ values of Kefir were measured with a microprocessor $\mathrm{pH}$ meter equipped with a glass electrode and a temperature probe (HANNA INSTRUMENTS model 22x, ANN ARBOR, USA). The titratable acidity (TA) was measured in triplicate by the titration of $10 \mathrm{~mL}$ sample with phenolphthalein against $0.11 \mathrm{M} \mathrm{NaOH}$ (James, 1999). TA is expressed as \% total acids.

\section{Consumer preference analysis}

The consumer preference test was conducted with a group of 85 consumers, which regularly consume non-sweetened fermented dairy products such as maas, Greek and Bulgarian yoghurts. Consumers were presented with a set of four 15 $\mathrm{mL}$ samples of each variant of kefir, served according to a randomised complete block design. Consumers rated each sample for liking on a 9-point hedonic scale: Like extremely (9), Like very much (8), Like moderately (7), Like slightly (6), Neither like nor dislike (5), Dislike slightly (4), Dislike moderately (3), Dislike very much (2) and Dislike extremely (1) (Lawless and Heymann, 2010).

\section{Statistical analysis}

Consumer sensory data were analysed using SAS ${ }^{\circledR}$ software (Version 9; SAS Institute Inc, Cary, USA) and subjected to the Shapiro-Wilk test for non- normality of the residuals (Shapiro and Wilk, 1965). Then, analysis of variance (ANOVA) was performed and student's t-least significant difference (LSD) was calculated at the $5 \%$ significance level to compare treatment means.

Ward's clustering was performed to cluster individual judges in terms of their liking of the four variants of Kefir with XLStat (Version 7.5.2, Addinsoft, New York, USA). ANOVA was performed, to determine the differences in preference patterns between clusters, with cluster as factor to test for Cluster*Sample interaction as well as separately for each cluster.

Principal component analysis (PCA) using the correlation matrix was conducted using XLStat (Version 7.5.2, Addinsoft, New York, USA) to visualise and elucidate the relationships between the samples and their attributes.

\section{RESULTS AND DISCUSSION}

\section{Metabolite profiles and acidity}

The results presented in Table 1 show acetaldehyde $\left(7-45 \mathrm{mg} \cdot \mathrm{L}^{-1}\right)$, ethanol (186 - $\left.1774 \mathrm{mg} . \mathrm{L}^{-1}\right)$, acetone $\left(4,5\right.$ - $\left.14 \mathrm{mg} . \mathrm{L}^{-1}\right)$, diacetyl $\left(5\right.$ - $\left.12 \mathrm{mg} . \mathrm{L}^{-1}\right)$, 2-butanone (1 $\left.-4 \mathrm{mg} . \mathrm{L}^{-1}\right)$, ethyl acetate $\left(1,2-30 \mathrm{mg} . \mathrm{L}^{-1}\right)$ and acetic acid $\left(892-4490 \mathrm{mg} . \mathrm{L}^{-1}\right)$ that were found in all variants of kefir. The differences observed when comparing these results to literature sources originate from differences in the microbial composition of the kefir grains, the inoculum size, the origin (cow, sheep, camel, soya) and type of milk (full cream, low-fat or fat free), the incubation time and the analytical methods used (Rea et al., 1996).

In terms of acidity, Trad-kefir was the most acidic product, with a $\mathrm{pH}$ of 4,13 and TA of $0,96 \%$. The reason for that could be that Trad-kefir was produced under uncontrolled conditions. For the other kefir types, the $\mathrm{pH}$ varied between 4,23 and 4,25; and TA between $0,85 \%$ and $0,90 \%$ (Tab 1). These values of $\mathrm{pH}$ and TA were within the range reported in the literature (Simova et al., 2002; Chen et al., 2009).

Kefir is known to have an acidic taste originating from the presence of lactic acid, associated with a buttery and slightly yeasty flavour. Although diacetyl plays an important role in the flavour of kefir, it has to be balanced with acetaldehyde. A balanced flavour is weighed by the ratio of diacetyl to acetaldehyde, which in most good cultured dairy products varies between 3 and 5 (Sandine et al., 1972; Kosikowski and Mistry, 1997). However in the case of kefir prepared with kefir grains, it appears that a lower ratio is more prevalent in kefir since the ratios found for the four variants varied between 0,12 and 1,07 The results are confirmed by literature sources, which also reported lower ratios $(0,0$ - 2,57) (Güzel-Seydim et al., 2000; Wszolek et al., 2001; Beshkova et al. 2003; Ntsame Affane, 2012). An exception was an extremely high ratio of 77 obtained in one study (Liu et al., 2002). where the concentration of diacetyl after $24 \mathrm{~h}$ of incubation at $254 \mathrm{mg} .1$-1Kefir prepared using soya milk also had higher ratios ranging between 10,5 and 16,6 (Liu et al., 2002; Pourahmad et al., 2011).

\section{Consumer preference analysis}

The PCA bi-plot (Fig 1) showed that Trad-kefir, which served as the control sample for this study, was associated with TA, ethanol, ethyl acetate, acetaldehyde and 2-butanone, whereas MG-kefir and Candi-kefir associated strongly with diacetyl and acetone. The figure 1 also shows that Lacto-kefir associated strongly with acetic acid. This distribution originates from the fact that traditional kefir had the highest concentrations in ethanol and ethyl acetate, Candi-kefir and MG-kefir had the highest concentration in diacetyl and acetone whereas Lacto-kefir had the highest concentration of acetic acid (Tab 1). The PCA analysis is in accordance with the obtained results.

Table 1 Metabolite profiles and acidity of the four variants of kefir. Results are expressed as mean \pm standard deviation (N=85)

\begin{tabular}{|c|c|c|c|c|c|c|c|c|c|c|}
\hline Kefir variants & $\mathrm{pH}$ & TA $(\%)$ & Acetaldehyde & Diacetyl & Ethanol & Acetone & 2-butanone & $\begin{array}{c}\text { Ethyl } \\
\text { acetate }\end{array}$ & Acetic acid & $\begin{array}{c}\text { Ratio diacetyl } \\
\text { to } \\
\text { acetaldehyde }\end{array}$ \\
\hline
\end{tabular}

mg. $\mathrm{L}^{-1}$

\begin{tabular}{|c|c|c|c|c|c|c|c|c|c|c|}
\hline Trad-kefir & 4,13 & 0,96 & $45 \pm 0,23$ & $5,5 \pm 1,9$ & $1774 \pm 252$ & $10 \pm 0,1$ & $4 \pm 1,0$ & $30 \pm 7,2$ & $1382 \pm 302$ & 0,12 \\
\hline Candi-kefir & 4,25 & 0,89 & $16 \pm 4,3$ & $12,1 \pm 6,7$ & $721 \pm 362$ & $12 \pm 1,6$ & $1 \pm 0,3$ & $1,5 \pm 0,4$ & $2431 \pm 178$ & 0,76 \\
\hline Lacto-kefir & 4,23 & 0,90 & $7 \pm 1,1$ & $5,1 \pm 2,2$ & $531 \pm 150$ & $4,5 \pm 1,7$ & $1,1 \pm 0,3$ & $1,2 \pm 0,3$ & $4490 \pm 560$ & 0,73 \\
\hline MG-kefir & 4,25 & 0,85 & $9 \pm 0,7$ & $9,6 \pm 4,4$ & $186 \pm 68,4$ & $14 \pm 1,4$ & $1,7 \pm 0,1$ & $11 \pm 1,9$ & $892 \pm 57$ & 1,07 \\
\hline
\end{tabular}




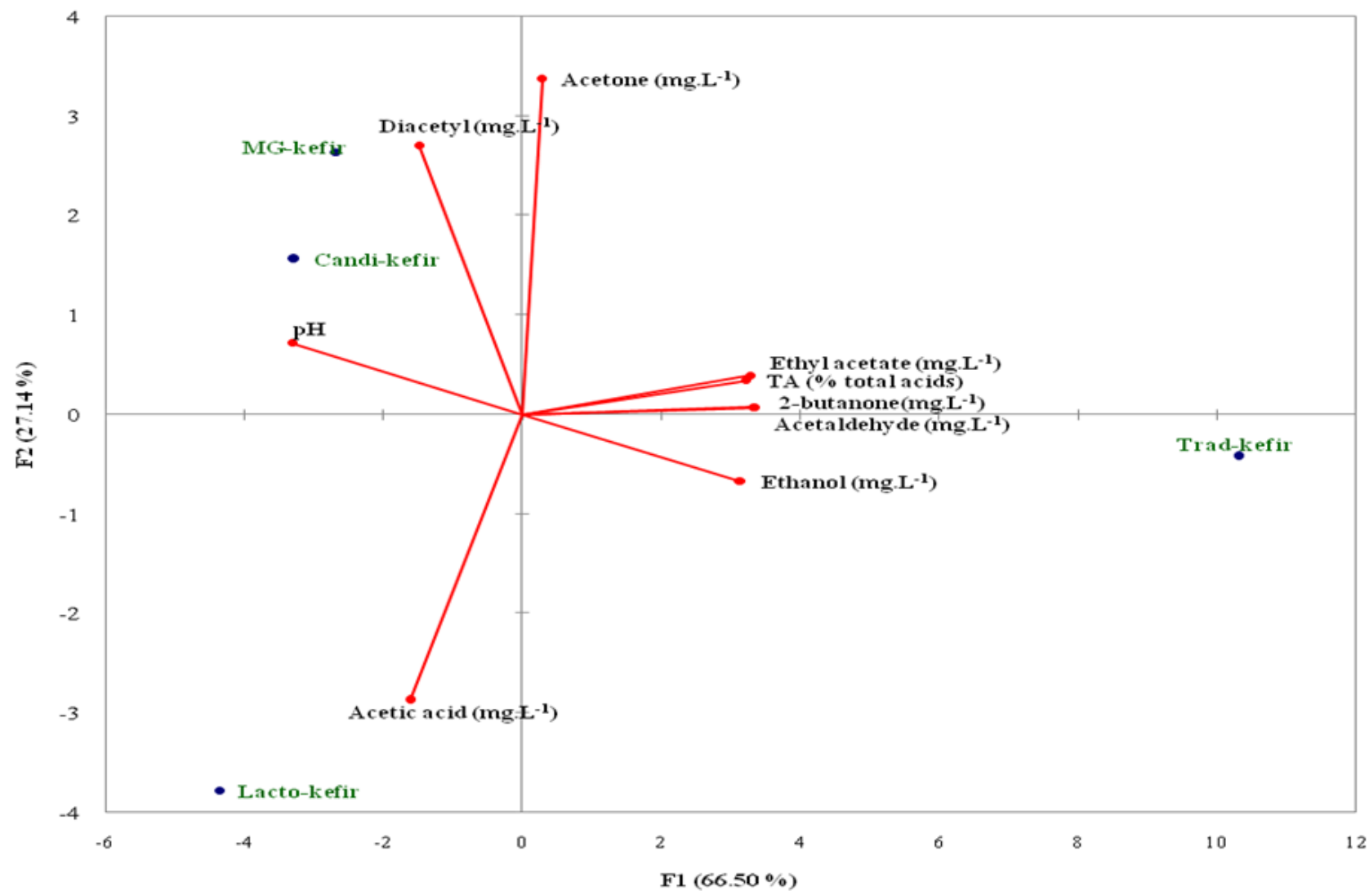

Figure 1 PCA bi-plot indicating the association of chemical constituents in relation to Trad-kefir, Candi-kefir, Lacto-kefir and MG-kefir

\section{Segmentation of consumer acceptability}

The composition of the total consumer group was not homogenous but mainly constituted by consumers of Bulgarian yoghurt (39\%), Greek yoghurt (31\%), buttermilk $(57 \%)$ and maas $39 \%$ than consumers of kefir (16\%). Thus, Ward's clustering was applied and three different clusters of consumers were identified, based on their degree of liking of the different variants of kefir.

The data in Table 2 clearly shows that the regular consumption of kefir, maas and buttermilk played a large role in the consumers clustering. After conducting the cluster analysis, the liking scores of each cluster for the flavour of the respective products were superimposed on the chemical data in a second PCA analysis (Fig 2).

Table 2 Demographic information and characteristics of each cluster expressed as percentage

\begin{tabular}{lccc}
\hline \hline $\begin{array}{l}\text { Consumers } \\
\mathrm{N}=85\end{array}$ & $\begin{array}{c}\text { Cluster I (\%) } \\
\mathrm{N}=36\end{array}$ & $\begin{array}{c}\text { Cluster II (\%) } \\
\mathrm{N}=20\end{array}$ & $\begin{array}{c}\text { Cluster III (\%) } \\
\mathrm{N}=44\end{array}$ \\
\hline \hline Kefir consumption & & & \\
NR & 100 & 50 & 83 \\
$\mathrm{R}$ & 0 & 50 & 17 \\
\hline Greek yogurt & & & \\
consumption & 61 & 75 & 66 \\
NR & 39 & 25 & 34 \\
$\mathrm{R}$ & & & \\
\hline Bulgarian yogurt & 55 & 69 & 63 \\
consumption & 45 & 31 & 37 \\
NR & & & \\
$\mathrm{R}$ & 79 & 62 & 43 \\
\hline Maas consumption & 21 & 38 & 57 \\
NR & & & \\
$\mathrm{R}$ & & 56 & 29 \\
\hline Buttermilk & & & \\
consumption & 48 & 44 & 71 \\
NR & 52 & & \\
$\mathrm{R}$ & & & \\
\hline \hline
\end{tabular}

$\mathrm{NR}=$ not regular; $\mathrm{R}=$ regular

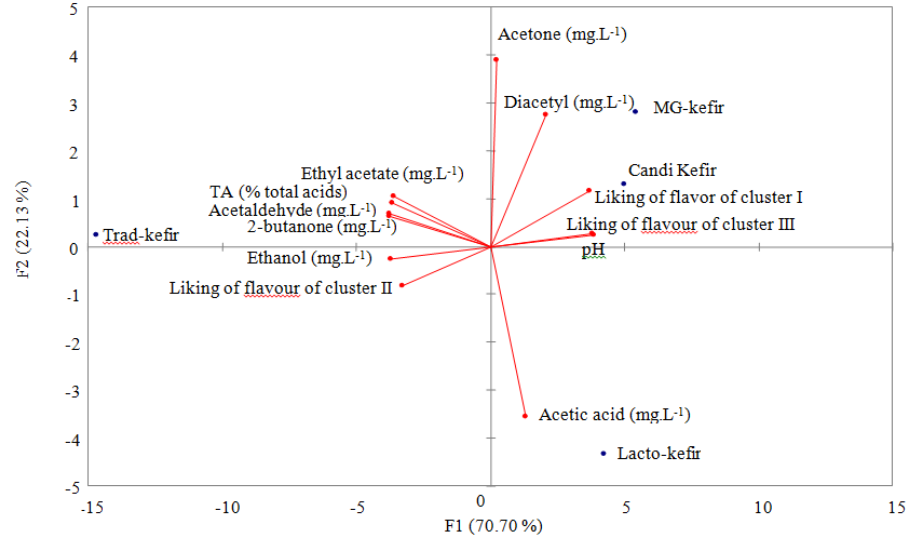

Figure 2 PCA bi-plot indicating the degree of liking of flavour of cluster I, II and III in relation to the four kefir samples and chemical constituents

\section{Cluster I}

Cluster I, representing $36 \%$ of consumer panel, had the particularity that none of the consumers $(0 \%)$ were regular consumers of kefir; but rather regular consumers of maas, Greek yoghurt, Bulgarian yoghurt and buttermilk (Tab 2).

This group of consumers gave low scores $(2,41$ to 5,30$)$ to all the variants of Kefir (Table 3), with the highest score obtained by Candi-kefir $(5,30)$ and the lowest score obtained by Trad-kefir. The most likely reason for the low scores is that this group of consumers has never consumed kefir products prior to the sensory analysis. In addition, less than $25 \%$ of this group drinks or uses maas regularly; and they are consequently unfamiliar with the naturally acidic taste of kefir. Furthermore, it could also be hypothesised that this group of consumers may have the tendency to sweeten (with fruits, honey or sugar) plain yoghurts and buttermilk or use them for baking purposes; making this consumer group quite unfamiliar with the natural acidity of traditional fermented dairy products (Doğan, 2011).

\section{Cluster II}

Consumers from cluster II represent $20 \%$ of the consumer panel and the preference liking of this cluster was significantly driven by ethanol content $(r=$ 0,$963 ; \mathrm{p}<0,05$ ) (Fig 2), which is responsible for the yeasty flavour in kefir. This yeasty flavour is an essential and definitive character of kefir. Thus, it can be suggested that consumers of cluster II enjoyed the 'yeasty flavour' of the four 
variants of kefir. This was confirmed by the results (Table 3), which indicated that the degree of liking of kefir types was associated with the quantity of ethanol present in the different variants of kefir. In keeping with these results, Trad-kefir obtained the best score $(7,5)$, followed by Candi-kefir $(6,31)$, Lacto-kefir $(5,94)$ and MG-kefir (4,87). The concentrations of ethanol in these products were 1774 mg.L $\mathrm{L}^{-1}, 720,5 \mathrm{mg} . \mathrm{L}^{-1} ; 531 \mathrm{mg} . \mathrm{L}^{-1}$ and $186 \mathrm{mg} . \mathrm{L}^{-1}$, respectively. In addition, the highest percentage regular consumers of kefir were found in this cluster (Table 2 ), which offers an additional explanation as to why traditional kefir obtained the best score $(7,5)$. This group of consumers also gave the lowest score to MG Kefir $(4,87)$, which was not surprising since regular kefir consumers would find the taste of MG-kefir untypical.

Different views are held regarding the 'strength' of the yeasty flavour in kefir. Some authors believe that kefir has a strong yeasty flavour (Marshall, 1984) whereas others believe that kefir has a weak yeasty flavour (Vedamuthu, 1977; Güzel-Seydim et al., 2000). Thus, considering the results obtained, it appears that consumers from cluster II preferred kefir that exhibited a strong yeasty flavour.

Table 3 Degree (max 9) of liking of flavour for Trad-kefir, Candi-kefir, Lactokefir and MG-kefir by cluster I, II and III. Means with different alphabetical letters differ significantly $(\mathrm{p}<0.05)$.

\begin{tabular}{lccc}
\hline \hline Samples & Cluster I & Cluster II & Cluster III \\
\hline \hline Trad-kefir & $2,41^{\mathrm{c}} \pm 1,15$ & $7,50^{\mathrm{a}} \pm 0,97$ & $4,91^{\mathrm{c}} \pm 1,60$ \\
\hline Candi-kefir & $5,27^{\mathrm{a}} \pm 2,03$ & $6,31^{\mathrm{ab}} \pm 2,24$ & $7,63^{\mathrm{a}} \pm 0,97$ \\
\hline Lacto-kefir & $4,20^{\mathrm{b}} \pm 2,11$ & $5,94^{\mathrm{bc}} \pm 1,53$ & $7,09^{\mathrm{b}} \pm 0,96$ \\
\hline MG-kefir & $5,14^{\mathrm{a}} \pm 2,15$ & $4,87^{\mathrm{c}} \pm 1,45$ & $7,29^{\mathrm{ab}} \pm 1,04$ \\
\hline \hline
\end{tabular}

\section{Cluster III}

Cluster III comprised the largest group of consumers (44\%) and for this group, $\mathrm{pH}$ was the driver of liking $(\mathrm{r}=0,999 ; \mathrm{p}<0,05)$ (Fig 2). The preference pattern of cluster III appeared to be similar to that of cluster I. As with cluster I, this cluster indicated the highest preference for Candi-kefir with a rating of 7,63, whereas Trad-kefir obtained the lowest mean score $(4,91)$ (Table 3$)$. This group did, however, give considerably higher scores to all these products $(4,91-7,63)$ when compared to consumers from cluster I $(2,41-5,30)$ (Table 3$)$.

The high scores for liking of the flavour $(7.09$ - 7.63) obtained for Candi-kefir Lacto-kefir and MG-kefir may originate from the fact that these types of kefir were mildly acidic products $(\mathrm{pH}=4,23-4,25)$ as opposed to Trad-kefir, which was moderately acidic $(\mathrm{pH}=4.13)$. This study confirmed previous findings that acidity perception generally determines the acceptability of fermented dairy products (Ott et al., 2000).

Furthermore, it is interesting to note that the liking scores obtained for Candikefir $(7,63)$, MG kefir $(7,29)$ and Lacto-kefir $(7,09)$ decreased as the content of diacetyl decreased. Diacetyl concentrations were $12 \mathrm{mg} . \mathrm{L}^{-1}, 9,6 \mathrm{mg} . \mathrm{L}^{-1}$ and 5 mg. $L^{-1}$ for Candi-kefir, MG-kefir and Lacto-kefir, respectively. Although the driver of liking of flavour for cluster III was not strongly driven by diacetyl ( $r=$ $0,646 ; p>0.05)$, it is possible that as a high proportion of cluster III consumers drink buttermilk regularly $(71 \%)$, the buttery flavour of kefir types could have prompted the preference ratings of these consumers. Indeed, the buttery flavour imparted by diacetyl, which concentration ranges between 1 and $4 \mathrm{mg} . \mathrm{L}^{-1}$ is the prominent flavour found in buttermilk (Vedamuthu, 2006).

\section{CONCLUSION}

Amongst the variants of kefir tasted, Candi-kefir was generally preferred by mos of the consumer panel. This is an indication that mass cultured kefir grain enriched with Candida kefyr (MGC) has the potential to be successfully marketed to South African consumers. However, the other variants of kefir, included Tradkefir the most acidic variant, would also have a market within the population as shown by the results.

This study has provided some understanding on the preference liking of kefir, a cultured dairy product unknown to South African consumers. It clearly appears different patterns of consumer liking driven by the perception of acidity and the volatile organic compounds diacetyl, and ethanol. Thus, further work on the identification of sensory attributes (eg. sweetness, saltiness, bitterness, astringency, acidity, fruitiness, creaminess), which drive the liking of South African consumers within specific consumer segments will further elucidate the viability of marketing kefir in South Africa.

In addition, this study also showed that drawing conclusions only based on the calculation of ratio of diacetyl to acetaldehyde may be inappropriate and should preferably be associated with a sensory testing.
Acknowledgments: This study was done at the Food Science Department (Stellenbosch University) and supported by the National Research Funding (South Africa).

\section{REFERENCES}

BAKHSHANDEH, T., POURAHMED, R., SHARIFAN, A. 2011. Evaluation of flavour and aroma compounds present in kefir. Journal of Biosciences and Technology, 1, 11-18.

BESHKOVA, D.M., SIMOVA, E.D., FFRENGOVA, G.I., SIMOV, Z.I DIMITROV, Zh.P. 2003. Production of volatile aroma compounds by Kefir starter cultures. International Dairy Journal, 13(7), 529-535. http://dx.doi.org/10.1016/S0958-6946(03)00058-x

BURGER, L. 2010. Amasi's sweet success. The Dairy Mail, August 2010.

CHEN, T-H., WANG, S-Y., CHEN, K-N., LIU, J-R., CHEN, M-J. 2009. Microbiological and chemical properties of kefir manufactured by entrapped microorganisms isolated from kefir grains. Journal of Dairy Science, 92, 3002 3013. http://dx.doi.org/10.3168/jds.2008-1669

COETZEE, K. 2011. Australian dairy upbeat - South African situation. The Dairy Mail, 18, 7-11.

DOĞAN, M. 2011. Rheological behaviour and physicochemical properties of kefir with honey. Journal of Consumer Protection and Food Safety, 6, 327-332. http://dx.doi.org/ 10.1007/s00003-010-0643-6

GRØNNEVIK, H., FALSTAD, M., NARVHUS, J. A. 2011. Microbiological and chemical properties of Norwegian kefir during storage. International Dairy Journal, 21, 601-606. http://dx.doi.org/10.1016/j.idairyj.2011.01.001

GÜZEL-SEYDIM, Z., SEYDIM, A.C., GREENE, A.K., BODINE, A.B. 2000 Determination of organic acids and volatile flavour substances in kefir during fermentation. Journal of Food Composition and Analysis, 13, 35-43. http://dx.doi.org/10.1006/jfca.1999.0842

HUMAN, M.E. 1998. Optimisation of Maas process parameters to achieve traditional flavour, aroma and texture. MSc in Food Science Thesis, University of Stellenbosch, South Africa.

JAMES, C.S. (1999). Analytical Chemistry of Foods. Great Britain: Chapman \& Hall. Pp. 168-169. ISBN 9780834212985.

KEBEDE, A., VILJOEN, B.C., GADAGA, T.H., NARVHUS, J.A., LOURENS HATTINGH, A. 2007. The effect of container type on the growth of yeast and lactic acid bacteria during production of Sethemi, South African spontaneously fermented milk. Food Research International, 40, 33-38. http://dx.doi.org/10.1016/i.foodres.2006.07.012

KOSIKOWSKI, F.V., MISTRY, V.V. 1997. Cheese and Fermented milks Westport, Connecticut: F.V. Kosikowski, L.L.C. Pp. 61-62. ISBN 9780965645621.

LAWLESS, H. T., HEYMANN, H. 2010. Sensory Evaluation of Food: Principles and Practices. New York: Springer. Pp. 326-328. ISBN 083421752X.

LIU, J-R., LIN, C-W. 2000. Production of kefir from soymilk with or withou added glucose, lactose or sucrose. Journal of Food Science, 65, 716-719. http://dx.doi.org/10.1111/j.1365-2621.2000.tb16078.x

LIU, J-R., CHEN, M-J., LIN, C-W. 2002. Characterisation of polysaccharide and volatile compounds produced by kefir grains grown in soymilk. Food Chemistry and Toxicology, 67, 104-108. http://dx.doi.org/10.1111/j.13652621.2002.tb11367.x

MARSHALL, V.M.E. 1984. Fermented milks: new developments in the biochemistry of the starter cultures. Biochemical Society Transactions, 12, 11501152. http://dx.doi.org/10.1042/bst0121150

NTSAME AFFANE, A.L. 2012. Impact of environmental factors on the metabolic profiles of kefir produced using different kefir grains and subsequent enrichment of kefir prepared with mass cultured kefir grains. $\mathrm{PhD}$ in Food Science Dissertation, University of Stellenbosch, South Africa.

OTT, A., HUGI, A., BAUMGARTNER, M., CHAINTREAU A. 2000. Sensory investigation of yogurt flavour perception: mutual influence of volatiles and acidity. Journal of Agriculture and Food Chemistry, 48, 44-450. http://dx.doi.org/10.1021/jf990432x

POURAHMAD, R., MOGHIMI, A., DADKHAH, S., ASSADI, M.M. 2011 Evaluation of flavour and aroma compounds amounts in Kefir from soymilk. World Applied Sciences Journal, 15, 673-676.

REA, M.C., LENNARTSSON, T., DILLON, P., DRINAN, F.D., REVILLE, W.J., HEAPES, M., COGAN, T.M. 1996. Irish kefir-like grains: their structure, microbial composition and fermentation kinetics. Journal of Applied Bacteriology, 81, 83-94. http://dx.doi.org/10.1111/j.1365-2672.1996.tb03286.x

SANDINE, W.E., DALY, C., ELLIKER, P.R., VEDAMUTHU, E.R. 1972 Causes and control of cultured-related flavour defects in cultured dairy products Journal of Dairy Science, 55, 1031-1039. http://dx.doi.org/10.3168/jds.S00220302(72)85617-0

SHIRATSUCHI, H., SHIMODA, M., IMAYOSHI, K., NODA, K., OSAJIMA, Y. 1994. Volatile flavour compounds in spray-dried skim milk powder. Journa of Agriculture and Food Chemistry, 42, 984-988. http://dx.doi.org/10.1021/jf00040a028 
SCHOEVERS, A., BRITZ, T.J. 2003. Influence of different culturing conditions on kefir grain increase. International Journal of Dairy Technology, 56, 183-187. http://dx.doi.org/10.1046/j.1471-0307.2003.00104.x

SCHÖNFELDT, H.C., GIBSON, N., VERMEULEN, H. 2010. The possible impact of inflation on nutritionally vulnerable households in a developing country using South Africa as a case study. Nutrition Bulletin, 35, 254-267. http://dx.doi.org/10.1111/j.1467-3010.2010.01837.x

SHAPIRO, S.S., Wilk, M. B. 1965. An analysis of variance test for normality (complete samples). Biometrika, 52, 591-611. http://dx.doi.org/10.1093/biomet/52.3-4.591

SIGGE, G.O., BRITZ, T.J., FOURIE, P.C., Barnardt, C.A. 2005. The efficiency of ozone as a pre- and post-treatment option for UASB-treated food processing waste waters. Water Science and Technology, 52, 167-173.

SIMOVA, E., BESHKOVA, D., ANGELOV. A., HRISTOZOVA, T., FRENGOVA, G., SPASOV, Z. 2002. Lactic acid bacteria and yeasts in kefir grains and kefir made from them. Journal of Industrial Microbiology \& Technology, 28, 1-6. http://dx.doi.org/10.1038/sj/jim/7000186

VAN WYK, J., BRITZ, T.J., MYBURGH, A.S. 2002. Arguments supporting kefir marketing to the low-income urban African population in South Africa. Agrekon, 41, 43-61.

VEDAMUTHU, E.R. 1977. Exotic fermented dairy products. Journal of Food Protection, 40, 801-802.

VEDAMUTHU, E.R. 2006. Manufacturing Yoghurt and Fermented Milks. Oxford: Blackwell Publishing. Pp. 89-116. ISBN 9781119967088.

WITTHUHN, R.C., SCHOEMAN, T., BRITZ, T.J. 2005. Characterisation of the microbial population at different stages of kefir production and kefir mass cultivation. International Dairy Journal, 15, 383-389. http://dx.doi.org/10.1016/j.idairyj.2004.07.016

WSZOLEK, M., TAMIME, A.Y., MUIR, D.D., BARCLAY, M.N.I. 2001 Properties of kefir made in Scotland and Poland using bovine, caprine and ovine with different starter cultures. Lebensmittel-Wissenschaft und-Technologie, 34, 251-261. http://dx.doi.org/10.1006/fstl.2001.0773 